\title{
STUDIES ON THE EFFECTS OF Bacillus thuringiensis AND NUCLEAR POLYHEDROSIS VIRUS (NPV) FOR CONTROLLING THE COTTON LEAFWORM Spodoptera littoralis ( NOCTUIDAE : LEPIDOPTERA) Abed-EI Wahab, I. S.; Samia Z. Sayed and M.M. Aly \\ Plant Protection Res. Instit.,Agric. Res. Cent. Dokki, Giza, Egypt.
}

\begin{abstract}
Effects of Bacillus thuringiensis and nuclear Polyhedrosis virus (NPV) mixture on certain biological aspects of Spodoptera littoralis were evaluated.

Both of $2^{\text {nd }}$ and $4^{\text {th }}$ larval instars of Spodoptera littoralis were used for that purpose. The mixture of both Bacillus thuringiensis (Dipel 2X) and nuclear Polyhedrosis virus (NPV) were slight effective against $2^{\text {nd }}$ and $4^{\text {th }}$ larval instars of Spodoptera littoralis. Generally the Bacillus thuringiensis treated leaves was more effective than other one of nuclear Polyhedrosis virus (NPV) in the respect of larval, pupal mortality and larval; pupal and adult duration.

This Bacillus thuringiensis (Dipel $2 \mathrm{X}$ ) and nuclear Polyhedrosis virus (NPV) also reduced the fecundity of alive females and of the treated larvae of the $4^{\text {th }}$ larval instar of Spodoptera littoralis.
\end{abstract}

\section{INTRODUCTION}

The use of insecticides may lead to biological imbalance due to the destruction of species, which attack the harmful insects. Besides the destruction of beneficial pollinator insects such as honey bees and others.

The cotton leafworm, Spodoptera littoralis (Boisd.) is considered as one of the most serious insect pests of many different Egyptian crops, where the pest attacks in heavy damage in all different parts of the host plants. The pesticidal and biological activities of Bacillus thuringiensis were extensively studied by several researchers, i.e. Abdel-Aziz and S. Hanan (2000) ; AbdelHalim (1993) ; Abdel-Halim et al (1997); Abou-Bakr, H. (1997) ; Aly, et al (2000) ; Belisle, et al (1990) ; Bernhard, et al (1997) ; Broza, M. and Sneh, B. (1994) ; Butani, et al (1997) ; Chaufaux, et al (1997) ; Dabi, et al (1988) ; ElSayed, A.K. and Lotfy, N. M (1990) ; Gadallah, et al (1990) ; Morris, et al (1996) ; Peng, et al (1992)

Therefore, the present work is carried out to determine the effect of $B$. thuringiensis and nuclear Polyhydrosis virus (NPV) on certain biological aspects in Spodoptera littorals. This can be attained by determining their possible latent effects on certain biological aspects.

\section{MATERIAL AND METHODS}

\section{Laboratory experiments :}

These experiments were carried out to study the effects of nuclear polyhedrosis virus (NPV) and Bacillus thuringiensis (B.T.) on different biological aspects of Spodoptera littoralis at different concentration of them .Oral administration was under taken by feeding the second and fourth instar larvae of $S$. littoralis on castor leaves. The effects of the mixture of these compound also were assessed. The tested biological aspects of 
Spodoptera littoralis were larval mortality, deformed larvae, larval duration, pupation, pupal mortality, deformed pupae, pupal duration, emerged moths, fecundity, eggs hatchability and moth longevity.

Insect culture:

The original culture of Egyptian cotton leafworm, Spodoptera littoralis (Boisd.) were obtained from Plant Protection Research Institute in Dokki, Giza, Egypt which reared on castor bean leaves. The culture was maintained at $28+2 \stackrel{\circ}{\circ} \mathrm{C}$ and $55+5 \%$ R.H. The progeny of these insects together with occasional fresh supplies of eggs, formed the basis of a culture designed to provide insects used in the present investigation.

Mortality was corrected according to Abbott's formula (1925) before probit analysis.

The tested compounds :

Two compounds were tested solely and together, they were:-

Polyhedrosis virus :

The production, preparation, formulation, testing and application of a microbial pesticide according to Mckinley ( 1985 ) rate of $5 \times 10^{12} /$ feddan. (300 gm /200 L. water) feddan.

Bacterial bioinsecticide :

B. thuringiensis var . Kurstaki as Dieple $2 \times\left(32 \times 10^{3} \mathrm{IU} / \mathrm{mg}\right.$. . The compound was used at the rate of $300 \mathrm{gm}$ powder. (300 gm /200 L. water).

Statistical analysis:

The entire assays were repeated two times each and the results were combined for statistical analysis. The results are presented as percentages, although actual means numbers of insects were used for statistical tests. Statistical significance was determined by analysis of variance (T-test at P.0.05) using the software package Costat. Results are recorded as mean \pm standard deviation (SD) according to Snedecor,(1971).

\section{RESULTS AND DISCUSSION}

Effect of, B. thuringiensis and nuclear Polyhedrosis virus (NPV) mixture on certain biological aspects of Spodoptera littoralis treated in $2^{\text {nd }}$ larval instar.

When $2^{\text {nd }}$ larval instar of Spodoptera littoralis were fed on castor oil leaves treated with the mixture of $B$. thuringiensis (Bacterial pathogen) and nuclear Polyhedrosis virus (NPV), many biological aspects were affected (Tables 1, 2 and 3). It is clear from the previous Tables, that the percentages means of larval mortality increased by increasing the mixture concentrations. The general averages of the two tested seasons in Table 3.A, were 60, 44.5, $36.5,27$ and $11.5 \%$ at the concentrations of $100,75,50.25$ and $12.5 \%$ of the mixture respectively, compared to no mortality percentages in control treatment. On the other hand, the general deformed larvae percentage mean were $2.5,2,2,2.5$ and $2 \%$ at concentrations of $100,75,50.25$ and $12.5 \%$ respectively, compared to undeformed larvae in control treatment.

According to the data presented in table $(1,2 \& 3)$, it is clear that a significant prolongation in larval duration periods of $S$. littoralis insect were noticed by decreasing of the tested Bacterial and viral mixture concentrations the general obtained larval duration were $10.6 \pm 0.54,10.8 \pm 0.58,11.2 \pm$ 
$0.64,11.6 \pm 0.62$ and $12.2 \pm 0.63$ at concentrations of $100,75,50.25$ and $12.5 \%$ days respectively (Table $3 \mathrm{~B}$ ), compared control (16 days).

Table (1): Effect of $B$. thuringiensis (Diple 2X) and nuclear ployhedrosis virus (SNPV) mixture on certain biological aspects of $2^{\text {nd }}$ instar of Spodoptera littoralis (Boisd) during 2004 at different concentrations of the compound.

\begin{tabular}{|c|c|c|c|c|c|c|c|}
\hline Concent. & 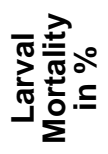 & 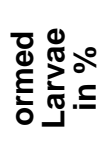 & $\begin{array}{l}\text { 등 } \\
\text { 융ㅇำ } \\
\text { 윽. } \\
0\end{array}$ & 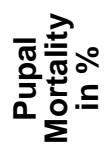 & 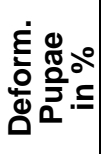 & 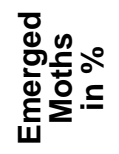 & 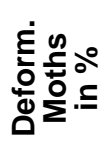 \\
\hline$A+B 100 \%$ & $65 \%$ & $4 \%$ & $31 \%$ & $6 \%$ & $0 \%$ & $20 \%$ & $5 \%$ \\
\hline$A+B 75 \%$ & $43 \%$ & $1 \%$ & $56 \%$ & $6 \%$ & $4 \%$ & $42 \%$ & $4 \%$ \\
\hline$A+B 50 \%$ & $35 \%$ & $2 \%$ & $63 \% 5$ & $8 \%$ & $0 \%$ & $49 \%$ & $6 \%$ \\
\hline$A+B 25 \%$ & $25 \%$ & $3 \%$ & $72 \%$ & $9 \%$ & $4 \%$ & $55 \%$ & $4 \%$ \\
\hline$A+B \quad 12.5 \%$ & $10 \%$ & $3 \%$ & $87 \%$ & $10 \%$ & $5 \%$ & $67 \%$ & $5 \%$ \\
\hline Untreated & $0 \%$ & $0 \%$ & $100 \%$ & $0 \%$ & $0 \%$ & $100 \%$ & $0 \%$ \\
\hline
\end{tabular}

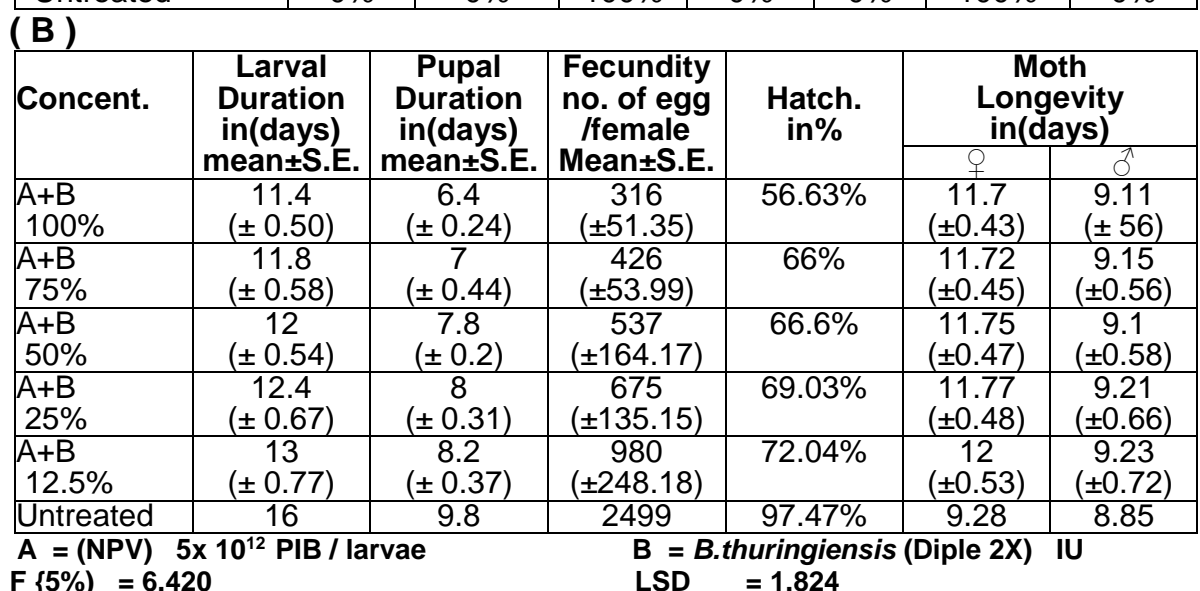

Also pupal stage, which resulted from treated $2^{\text {nd }}$ larvae instar of $S$. littoralis, with this mixture were affected as shown in Tables (1, $2 \& 3)$. The general percentages averages of pupation were increased by decreasing the concentrations of mixture. The pupation averages were 37.5, 53.5, 61.5, 70.5 and $86.5 \%$ at mixture concentrations of $100,75,50.25$ and $12.5 \%$ respectively, compared to $100 \%$ pupation in control treatment (Table 3A). While, the mean percentages of pupal mortality were $5.5,5,5.5,7$ and $10 \%$ at the previously mentioned concentrations respectively, compared to no mortality for the control. Also, the mean percentage of deformed pupae were reduced to $0,4,0,2$ and $5 \%$ at the concentrations of 100,75,50, 25 and $12.5 \%$ respectively, compared to no deformed pupae for the control larvae (Table 3A). 
Table (2): Effect of B. thuringiensis (Diple 2x) and Nuclear Ployhedrosis virus (SNPV) mixture on certain biological aspects of $2^{\text {nd }}$ instar of Spodoptera littoralis (Boisd) during 2005 at different concentrations of the compounds.

( A)

\begin{tabular}{|l|c|c|c|c|c|c|c|}
\hline Concent. & $\begin{array}{c}\text { Larval } \\
\text { Mortality } \\
\text { in } \%\end{array}$ & $\begin{array}{c}\text { Deformed } \\
\text { Larvae } \\
\text { in } \%\end{array}$ & $\begin{array}{c}\text { Pupation } \\
\text { in } \%\end{array}$ & $\begin{array}{c}\text { Pupal } \\
\text { Mortality } \\
\text { in } \%\end{array}$ & $\begin{array}{c}\text { Deform. } \\
\text { Pupae } \\
\text { in } \%\end{array}$ & $\begin{array}{c}\text { Emerged } \\
\text { Moths } \\
\text { in } \%\end{array}$ & $\begin{array}{c}\text { Deform. } \\
\text { Moths } \\
\text { in } \%\end{array}$ \\
\hline $\mathrm{A}+\mathrm{B} 100 \%$ & $55 \%$ & $1 \%$ & $44 \%$ & $5 \%$ & $0.0 \%$ & $33 \%$ & $6 \%$ \\
\hline $\mathrm{A}+\mathrm{B} 75 \%$ & $46 \%$ & $3 \%$ & $51 \%$ & $4 \%$ & $4 \%$ & $40 \%$ & $3 \%$ \\
\hline $\mathrm{A}+\mathrm{B} 50 \%$ & $38 \%$ & $2 \%$ & $60 \%$ & $3 \%$ & $0.0 \%$ & $51 \%$ & $6 \%$ \\
\hline $\mathrm{A}+\mathrm{B} 25 \%$ & $29 \%$ & $2 \%$ & $69 \%$ & $3 \%$ & $0.0 \%$ & $60 \%$ & $4 \%$ \\
\hline $\mathrm{A}+\mathrm{B} 12.5 \%$ & $13 \%$ & $1 \%$ & $86 \%$ & $10 \%$ & $5 \%$ & $68 \%$ & $3 \%$ \\
\hline Untreated & $0.0 \%$ & $0.0 \%$ & $100 \%$ & $0.0 \%$ & $0.0 \%$ & $100 \%$ & $0 \%$ \\
\hline
\end{tabular}

\begin{tabular}{|c|c|c|c|c|c|c|}
\hline \multicolumn{7}{|l|}{ B ) } \\
\hline \multirow[t]{2}{*}{ Concent. } & \multirow[t]{2}{*}{ 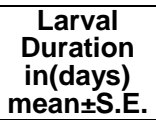 } & \multirow[t]{2}{*}{$\begin{array}{c}\text { Pupal } \\
\text { Duration } \\
\text { in(days) } \\
\text { mean } \pm \text { S.E. }\end{array}$} & \multirow[t]{2}{*}{$\begin{array}{c}\text { Fecundity } \\
\text { no. of egg } \\
\text { /female } \\
\text { Mean } \pm \text { S.E. }\end{array}$} & \multirow[t]{2}{*}{$\begin{array}{c}\text { Hatch. } \\
\text { in \% }\end{array}$} & \multicolumn{2}{|c|}{$\begin{array}{c}\text { Moth } \\
\text { Longevity } \\
\text { in(days) }\end{array}$} \\
\hline & & & & & 웅 & $\sigma^{\pi}$ \\
\hline $\begin{array}{l}A+B \\
100 \%\end{array}$ & $\begin{array}{c}9.8 \\
( \pm 0.58)\end{array}$ & $\begin{array}{c}4.8 \\
( \pm 0.37)\end{array}$ & $\begin{array}{c}516 \\
( \pm 99.45)\end{array}$ & $57.6 \%$ & $\begin{array}{c}10.6 \\
( \pm 0.35)\end{array}$ & $\begin{array}{c}8.21 \\
( \pm 51)\end{array}$ \\
\hline $\begin{array}{l}A+B \\
75 \%\end{array}$ & $\begin{array}{c}9.8 \\
\pm 0.58) \\
\end{array}$ & $\begin{array}{c}5.4 \\
( \pm 0.24)\end{array}$ & $\begin{array}{c}620 \\
( \pm 120.1)\end{array}$ & $68.06 \%$ & $\begin{array}{c}10.2 \\
( \pm 0.43)\end{array}$ & $\begin{array}{c}8.14 \\
( \pm 0.51)\end{array}$ \\
\hline $\begin{array}{l}A+B \\
50 \%\end{array}$ & $\begin{array}{c}10.4 \\
( \pm 0.75) \\
\end{array}$ & $\begin{array}{c}5.8 \\
( \pm 0.37) \\
\end{array}$ & $\begin{array}{r}757 \\
( \pm 154.9) \\
\end{array}$ & $69.6 \%$ & $\begin{array}{c}10.8 \\
( \pm 0.42)\end{array}$ & $\begin{array}{c}8.2 \\
( \pm 0.52)\end{array}$ \\
\hline $\begin{array}{l}A+B \\
25 \%\end{array}$ & $\begin{array}{c}10.8 \\
( \pm 0.58)\end{array}$ & $\begin{array}{c}6.4 \\
( \pm 0.24)\end{array}$ & $\begin{array}{c}870 \\
( \pm 194.16)\end{array}$ & $77.1 \%$ & $\begin{array}{c}10.8 \\
( \pm 0.44)\end{array}$ & $\begin{array}{c}8.24 \\
( \pm 0.67)\end{array}$ \\
\hline $\begin{array}{l}A+B \\
12.5 \%\end{array}$ & $\begin{array}{c}11.4 \\
( \pm 0.50) \\
\end{array}$ & $\begin{array}{c}6.6 \\
( \pm 0.24) \\
\end{array}$ & $\begin{array}{c}975 \\
( \pm 210.35) \\
\end{array}$ & $79.48 \%$ & $\begin{array}{c}11.2 \\
( \pm 0.51) \\
\end{array}$ & $\begin{array}{c}8.22 \\
( \pm 0.76) \\
\end{array}$ \\
\hline Untreated & 16 & 8.6 & 2250 & $99.28 \%$ & 9.9 & 8.6 \\
\hline $\begin{array}{l}\text { NB:-A }=(\text { NP } \\
F\{5 \%)=5 .\end{array}$ & $5 \times 10^{12} P$ & larvae & & $\begin{array}{l}\text { uringien } \\
=1.00\end{array}$ & Diple & IU \\
\hline
\end{tabular}

Data in table (3B), also show a significant effect of mixture of $B$. thuringiensis and nuclear Polyhedrosis virus (NPV) on the duration of the pupae produced from treated $2^{\text {nd }}$ larval instar of $S$. littoralis. The pupal duration were $5.6 \pm 0.30,6.2 \pm 0.34,6.8 \pm 0.28,7.2 \pm 0.27$ and $7.4 \pm 0.30$ days at the concentrations of $100,75,50.25$ and $12.5 \%$ respectively, compared to 9.2 days obtained by the larvae in control treatment.

In the case of adults resulted from treated $2^{\text {nd }}$ larval instar of $S$. littoralis, the percentages means of emerged, deformed moths, fecundity and eggs hatchability were greatly affected (Table.1,2,3). The general mean percentages averages in (table $3 \mathrm{~A}$ ) of emerged moths were 26.5, 41, 50, 57.5 and $67.5 \%$ at the previously mentioned concentrations respectively as compared to $100 \%$ emerged moths for control. While the deformed moths were $5.5,3.5,6,2$ and $4 \%$ respectively. The fecundity of females and eggs hatchability were affected, due to treatments of $2^{\text {nd }}$ larvae instar with mixture of $B$. thuringiensis and nuclear Polyhedrosis virus (NPV). The eggs mean number / female were $416 \pm 75.4,523 \pm 87.04,647 \pm 159.53,772.5 \pm$ 164.65 and $977.5 \pm 229.26$ at the previously mentioned concentrations respectively compared to 2374.5 eggs / female for control. Adult longevity also were affected by the treatment; whereas females longevity were $11.15 \pm$ $0.39,10.96 \pm 0.44,11.27 \pm 0.44,11.28 \pm 0.46$ and $11.6 \pm 0$. days and that of males were $8.66 \pm 0.53,8.64 \pm 0.53,8.65 \pm 0.55,8.71 \pm 0.66$ and $8.72 \pm$ 
0.74 days at mixture concentrations of $100,75,50.25$ and $12.5 \%$ respectively, as compared to 9.59 days for females and 8.73 days for males at control.

Table (3):The general means of certain biological aspects of $2^{\text {nd }}$ larval instar of Spodoptera littoralis affected by the mixture B.thuringiensis (Diple $2 \mathrm{X}$ ) and Nuclear polyhedrosis virus (SNPV) throughout the two tested years $(2004 \& 2005)$ at different concentration.

(A)

\begin{tabular}{|l|c|c|c|c|c|c|c|}
\hline Concent. & $\begin{array}{c}\text { Larval } \\
\text { Mortality } \\
\text { in } \%\end{array}$ & $\begin{array}{c}\text { Deformed } \\
\text { Larvae } \\
\text { in } \%\end{array}$ & $\begin{array}{c}\text { Pupation } \\
\text { in } \%\end{array}$ & $\begin{array}{c}\text { Pupal } \\
\text { Mortality } \\
\text { in } \%\end{array}$ & $\begin{array}{c}\text { Deform. } \\
\text { Pupae } \\
\text { in } \%\end{array}$ & $\begin{array}{c}\text { Emerged } \\
\text { Moths } \\
\text { in } \%\end{array}$ & $\begin{array}{c}\text { Deform. } \\
\text { Moths } \\
\text { in } \%\end{array}$ \\
\hline $\mathbf{A}+\mathbf{B} 100 \%$ & $60 \%$ & $2.5 \%$ & $37.5 \%$ & $5.5 \%$ & $0 \%$ & $26.5 \%$ & $5.5 \%$ \\
\hline $\mathrm{A}+\mathrm{B} 75 \%$ & $44.5 \%$ & $2 \%$ & $53.5 \%$ & $5 \%$ & $4 \%$ & $41 \%$ & $3.5 \%$ \\
\hline $\mathrm{A}+\mathrm{B} 50 \%$ & $36.5 \%$ & $2 \%$ & $61.5 \%$ & $5.5 \%$ & $0 \%$ & $50 \%$ & $6 \%$ \\
\hline $\mathrm{A}+\mathrm{B} 25 \%$ & $27 \%$ & $2.5 \%$ & $70.5 \%$ & $7 \%$ & $2 \%$ & $57.5 \%$ & $2 \%$ \\
\hline $\mathrm{A}+\mathrm{B} 12.5 \%$ & $11.5 \%$ & $2 \%$ & $86.5 \%$ & $10 \%$ & $5 \%$ & $67.5 \%$ & $4 \%$ \\
\hline Untreated & $0 \%$ & $0 \%$ & $100 \%$ & $0 \%$ & $0 \%$ & $100 \%$ & \\
\hline
\end{tabular}

\begin{tabular}{|c|c|c|c|c|c|c|}
\hline \multicolumn{7}{|l|}{ B ) } \\
\hline \multirow[t]{2}{*}{ Concent. } & \multirow{2}{*}{$\begin{array}{c}\text { Larval } \\
\text { Duration } \\
\text { in(days) } \\
\text { mean } \pm \text { S.E. }\end{array}$} & \multirow{2}{*}{$\begin{array}{c}\text { Pupal } \\
\text { Duration } \\
\text { in(days) } \\
\text { mean } \pm \text { S.E. }\end{array}$} & \multirow{2}{*}{$\begin{array}{c}\text { Fecundity } \\
\text { no. of egg } \\
\text { /female } \\
\text { Mean } \pm \text { S.E. }\end{array}$} & \multirow[t]{2}{*}{$\begin{array}{l}\text { Hatch. } \\
\text { in } \%\end{array}$} & \multicolumn{2}{|c|}{$\begin{array}{c}\text { Moth } \\
\text { Longevity } \\
\text { in(days) }\end{array}$} \\
\hline & & & & & 9 & $\sigma^{\pi}$ \\
\hline $\begin{array}{l}A+B \\
100 \%\end{array}$ & $\begin{array}{c}10.6 \\
( \pm 0.54) \\
\end{array}$ & $\begin{array}{c}5.6 \\
( \pm 0.30) \\
\end{array}$ & $\begin{array}{c}416 \\
( \pm 75.4) \\
\end{array}$ & $57.06 \%$ & $\begin{array}{r}11.15 \\
( \pm 0.39) \\
\end{array}$ & $\begin{array}{c}8.66 \\
( \pm 0.53) \\
\end{array}$ \\
\hline $\begin{array}{l}A+B \\
75 \%\end{array}$ & $\begin{array}{c}10.8 \\
( \pm 0.58)\end{array}$ & $\begin{array}{l}6.2 \\
( \pm 0.34)\end{array}$ & $\begin{array}{c}523 \\
( \pm 87.04) \\
\end{array}$ & $67.03 \%$ & $\begin{array}{c}10.96 \\
( \pm 0.44)\end{array}$ & $\begin{array}{c}8.64 \\
( \pm 0.53)\end{array}$ \\
\hline $\begin{array}{l}A+B \\
50 \%\end{array}$ & $\begin{array}{c}11.2 \\
( \pm 0.64)\end{array}$ & $\begin{array}{c}6.8 \\
( \pm 0.28)\end{array}$ & $\begin{array}{c}647 \\
( \pm 159.53)\end{array}$ & $68.1 \%$ & $\begin{array}{c}11.27 \\
( \pm 0.44)\end{array}$ & $\begin{array}{c}8.65 \\
( \pm 0.55)\end{array}$ \\
\hline $\begin{array}{l}A+B \\
25 \%\end{array}$ & $\begin{array}{c}11.6 \\
( \pm 0.62)\end{array}$ & $\begin{array}{c}7.2 \\
( \pm 0.27)\end{array}$ & $\begin{array}{c}772.5 \\
( \pm 164.65)\end{array}$ & $73.06 \%$ & $\begin{array}{c}11.28 \\
( \pm 0.46)\end{array}$ & $\begin{array}{c}8.71 \\
( \pm 0.66)\end{array}$ \\
\hline $\begin{array}{l}A+B \\
12.5 \%\end{array}$ & $\begin{array}{c}12.2 \\
( \pm 0.63)\end{array}$ & $\begin{array}{c}7.4 \\
( \pm 0.30)\end{array}$ & $\begin{array}{c}977.5 \\
( \pm 229.26)\end{array}$ & $72.76 \%$ & $\begin{array}{c}11.6 \\
( \pm 0.52)\end{array}$ & $\begin{array}{c}8.72 \\
( \pm 0.74)\end{array}$ \\
\hline Untreated & 16 & 9.2 & 2374.5 & $98.37 \%$ & 9.59 & 8.73 \\
\hline
\end{tabular}

$\mathrm{A}=(\mathrm{NPV}) \quad 5 \times 10^{12} \mathrm{PIB} /$ larvae $\mathrm{B}=$ B.thuringiensis (Diple 2X) IU

$F\{5 \%)=5.125$

LSD $\quad 0.954$

Effect of, B. thuringiensis and nuclear Polyhedrosis virus (NPV) Mixture of on cert, biological aspects on $4^{\text {th }}$ larvae instar of Spodoptera littoralis treated in the $4^{\text {th }}$ larvae instar :

When $4^{\text {th }} \quad$ larvae instar of Spodoptera littoralis were fed on treated castor oil plant leaves with mixture consists of $B$. thuringiensis and nuclear Polyhedrosis virus (NPV) several biological factors of this insect were influenced as shown in tables $(4,5,6)$. From the general averages data recorded in Table $(6 \mathrm{~A})$ it is clear that, the mean percentage of larval mortality increased by increasing the tested concentrations of the mixture. The mortality averages were $55,42,35,28$ and $13.5 \%$ at the concentrations of $100,75,50.25$ and $12.5 \%$ respectively compared to zero mortality in control treatment. On the other hand the percentages of deformed larvae were 2.5, $0.5,0$, and 1.5 and $0.0 \%$ by the tested concentrations of $100,75.50,25$ and $12.5 \%$ respectively, compared to zero deformed larvae in control. From these results, (in table 6B) a significant prolongation in larval duration, were 
noticed at concentrations of $100,75,50.25$ and $12.5 \%$. The general averages of larval periods were $6.8 \pm 0.61,6.8 \pm 0.51,7.4 \pm 0.52,7.6 \pm 0.67$ and $8.4 \pm 0.64$ days respectively, compared to 9 days for control larvae.

In case of pupal stage, which resulted from treated $4^{\text {th }}$ larval instar of $S$. littoralis, with the mixture, percentage of pupation, mortality, deformed pupae and the pupal duration, were affected From table $(4,5,6)$. The mean percentages of pupation increased by decreasing of concentrations of the mixture of $B$. thuringiensis and nuclear Polyhedrosis virus (NPV). The general averages of pupation percentages were 42.5, 57.5, 65, 70.5 and $86.5 \%$ at concentrations of $100,75,50,25$ and $12.5 \%$ respectively, compared to $100 \%$ pupation for control. While, the mean percentages of pupal mortality were $7.5,6.5,7.5 .5$ and $5 \%$ at the same previously mentioned concentrations respectively, compared to $2.5 \%$ mortality for the control. Also, the mean percentages of deformed pupae were reduced to 0 , $5,0,2$ and $4.5 \%$ at the concentrations of $100,75,50.25$ and $12.5 \%$ respectively, compared to no deformed pupae for the control table (6A).

The obtained pupal durations periods were $7 \pm 0.70,7 \pm 0.62,7.3 \pm$ $0.72,7.6 \pm 0.62$ and $7.8 \pm 0.75$ days at the mixture concentrations of 100,75 , 50.25 and $12.5 \%$ respectively, compared to 8.4 days for the control larvae Table (6B). The general averages of insect adult emergence, deformed moths, fecundity of females and eggs hatchability were greatly influenced when the $4^{\text {th }}$ larval instars of S.littoralis treated with (table. 6). At concentrations of $100,75,50.25$ and $12.5 \%$ of $B$. thuringiensis and nuclear Polyhedrosis virus (NPV) mixture. The mean percentages of emerged moths were $29,42,53.5,60$ and $74.5 \%$ respectively compared with $97.5 \%$ by control. The deformed moths percentages were $6.5,4,4.5,3$ and $2.5 \%$ respectively (table $6 \mathrm{~A}$ ). The fecundity and eggs hatchability of adult females also were affected, by treating the $4^{\text {th }}$ larval instars with this mixture (table $6 \mathrm{~B})$. The mean numbers of eggs per / female were $497 \pm 58.95,583 \pm$ $72.21,698.5 \pm 167.64,796.5 \pm 175.64$ and $902.5 \pm 239.15$ eggs/females at the previously mentioned concentrations, of the teasted bio-mixture, respectively compared to 2250 eggs / female in control treatment. The means of egg hatchability as percentages were $43.3,52.59,60.51,67.14$ and $71.78 \%$, while it was 98.66 by control. The females longevities were $6.71 \pm 0.23,6.86 \pm 0.33,7.06 \pm 0.40,7.21 \pm 0.57$ and $6.84 \pm 0.48$ days and that of males were $5.04 \pm 0.27,5.71 \pm 0.44,6.12 \pm 0.53,6.54 \pm 0.54$ and $6.90 \pm 0.23$ days at concentrations of $100,75,50.25$ and $12.5 \%$ of the mixture respectively, as compared to 9.1 days in females and 8.8 days in males for control (table 6B).

In the present study, Bacillus thuringiensis and nuclear Polyhedrosis virus (NPV) against $2^{\text {nd }}$ larvae instar of $S$. littoralis had slightly effects. On the other hand the mean percentage of pupation and adult emergence produced from the $2^{\text {nd }}$ and $4^{\text {th }}$ instars larvae of $S$. littoralis which fed on castor oil leaves treated with different concentrations of Bacillus thuringiensis and nuclear Polyhedrosis virus (NPV) were greatly affected. From the foregoing results, it could be concluded that in all cases, larval mortality increased by increasing in the concentrations of the mixture of the bacterial. On the contrary both larval and pupal durations decrease by increasing 
concentrations of the tasted bioinsecticidal compounds. In respect to adult stage, increasing concentrations led to decrease in female fecundity and adult longevity. All experiments proved that the effect of treatment with these compounds on the insect was higher when the treatments were carried out on the $2^{\text {nd }}$ larval instar than in the $4^{\text {th }}$ one. The general highest percentage of larval mortality was obtained when the larvae treated in the $2^{\text {nd }}$ instar with the tested mixture consists of B.thuringenal and NPV. Concentration of 100

Table (4): Effect of $B$. thuringiensis (Diple 2x) and Nuclear Ployhedrosis virus (SNPV) mixture on certain biological aspects of $4^{\text {th }}$ instar of Spodoptera littoralis (Boisd) during 2004 at different ( A ) concentrations of the compounds.

\begin{tabular}{|l|c|c|c|c|c|c|c|}
\hline Concent. & $\begin{array}{c}\text { Larval } \\
\text { Mortality } \\
\text { in } \%\end{array}$ & $\begin{array}{c}\text { Deformed } \\
\text { Larvae } \\
\text { in\% }\end{array}$ & $\begin{array}{c}\text { Pupation } \\
\text { in } \%\end{array}$ & $\begin{array}{c}\text { Pupal } \\
\text { Mortality } \\
\text { in } \%\end{array}$ & $\begin{array}{c}\text { Deformed } \\
\text { Pupae } \\
\text { in \% }\end{array}$ & $\begin{array}{c}\text { Emerged } \\
\text { Moths } \\
\text { in } \%\end{array}$ & $\begin{array}{c}\text { Deformed } \\
\text { Moths } \\
\text { in } \%\end{array}$ \\
\hline $\mathrm{A}+\mathrm{B} 100 \%$ & $54 \%$ & $3 \%$ & $43 \%$ & $7 \%$ & $0 \%$ & $31 \%$ & $5 \%$ \\
\hline $\mathrm{A}+\mathrm{B} 75 \%$ & $40 \%$ & $1 \%$ & $59 \%$ & $6 \%$ & $4 \%$ & $45 \%$ & $4 \%$ \\
\hline $\mathrm{A}+\mathrm{B} 50 \%$ & $32 \%$ & $0 \%$ & $68 \%$ & $8 \%$ & $0 \%$ & $54 \%$ & $6 \%$ \\
\hline $\mathrm{A}+\mathrm{B} 25 \%$ & $23 \%$ & $1 \%$ & $76 \%$ & $7 \%$ & $4 \%$ & $62 \%$ & $3 \%$ \\
\hline $\mathrm{A}+\mathrm{B} 12.5 \%$ & $8 \%$ & $0 \%$ & $92 \%$ & $8 \%$ & $3 \%$ & $76 \%$ & $5 \%$ \\
\hline Untreated & $0 \%$ & $0 \%$ & $100 \%$ & $5 \%$ & $0 \%$ & $95 \%$ & $0 \%$ \\
\hline
\end{tabular}

(B)

\begin{tabular}{|c|c|c|c|c|c|c|}
\hline \multirow[t]{2}{*}{ Concent. } & \multirow{2}{*}{$\begin{array}{c}\text { Larval } \\
\text { Duration } \\
\text { in (days) } \\
\text { mean } \pm \text { S.E. }\end{array}$} & \multirow{2}{*}{$\begin{array}{c}\text { Pupal } \\
\text { Duration } \\
\text { in (days) } \\
\text { mean } \pm \text { S.E. }\end{array}$} & \multirow{2}{*}{$\begin{array}{c}\text { Fecundity } \\
\text { no. of egg } \\
\text { /female } \\
\text { Mean } \pm S . E .\end{array}$} & \multirow[t]{2}{*}{$\begin{array}{c}\text { Hatch. } \\
\text { in } \%\end{array}$} & \multicolumn{2}{|c|}{$\begin{array}{c}\text { Moth } \\
\text { Longevity } \\
\text { in(days) }\end{array}$} \\
\hline & & & & & 9 & $\pi$ \\
\hline $\begin{array}{l}A+B \\
100 \% \\
\end{array}$ & $\begin{array}{c}5.8 \\
( \pm 0.37) \\
\end{array}$ & $\begin{array}{c}6 \\
( \pm 0.97) \\
\end{array}$ & $\begin{array}{c}514 \\
( \pm 58.452) \\
\end{array}$ & $75.36 \%$ & $\begin{array}{c}6.3 \\
( \pm 0.13) \\
\end{array}$ & $\begin{array}{c}4.08 \\
( \pm 32) \\
\end{array}$ \\
\hline $\begin{array}{l}A+B \\
75 \%\end{array}$ & $\begin{array}{c}5.8 \\
( \pm 0.37) \\
\end{array}$ & $\begin{array}{c}6 \\
( \pm 0.54)\end{array}$ & $\begin{array}{c}626 \\
( \pm 54.65) \\
\end{array}$ & $67.09 \%$ & $\begin{array}{c}6.6 \\
( \pm 0.32) \\
\end{array}$ & $\begin{array}{c}5.21 \\
( \pm 0.57) \\
\end{array}$ \\
\hline $\begin{array}{l}A+B \\
50 \%\end{array}$ & $\begin{array}{c}6.2 \\
( \pm 0.3)\end{array}$ & $\begin{array}{c}6.2 \\
( \pm 0.63) \\
\end{array}$ & $\begin{array}{c}737 \\
( \pm 152.99)\end{array}$ & $69.9 \%$ & $\begin{array}{c}6.6 \\
( \pm 0.71) \\
\end{array}$ & $\begin{array}{c}5.63 \\
( \pm 0.35) \\
\end{array}$ \\
\hline $\begin{array}{l}A+B \\
25 \%\end{array}$ & $\begin{array}{c}6.4 \\
( \pm 0.67)\end{array}$ & $\begin{array}{c}6.4 \\
( \pm 0.50)\end{array}$ & $\begin{array}{c}873 \\
( \pm 196.56)\end{array}$ & $77.09 \%$ & $\begin{array}{c}6.53 \\
( \pm 0.81)\end{array}$ & $\begin{array}{c}6.40 \\
( \pm 0.16)\end{array}$ \\
\hline $\begin{array}{l}A+B \\
12.5 \%\end{array}$ & $\begin{array}{c}7.6 \\
( \pm 0.68) \\
\end{array}$ & $\begin{array}{c}6.8 \\
( \pm 0.58)\end{array}$ & $\begin{array}{c}965 \\
( \pm 254.55)\end{array}$ & $79.06 \%$ & $\begin{array}{c}6.68 \\
( \pm 0.43) \\
\end{array}$ & $\begin{array}{c}6.82 \\
( \pm 0.24)\end{array}$ \\
\hline Untreated & 9 & 8.2 & 2240 & $98.08 \%$ & 9.6 & 9.2 \\
\hline
\end{tabular}

NB:-A = (NPV) $5 \times 10^{12}$ PIB / larvae

$F\{5 \%)=9.507$

$\mathrm{B}=$ B.thuringiensis IU

LSD $=1.872$

Table(5): Effect of $B$. thuringiensis (Diple $2 x$ ) and Nuclear Ployhedrosis virus (SNPV) mixture on certain biological aspects of $4^{\text {th }}$ instar of Spodoptera littoralis (Boisd) during 2005 at different concentrations of the compounds.

(A)

\begin{tabular}{|l|c|c|c|c|c|c|c|}
\hline Concent. & $\begin{array}{c}\text { Larval } \\
\text { Mortality } \\
\text { in } \%\end{array}$ & $\begin{array}{c}\text { Deformed } \\
\text { Larvae } \\
\text { in } \%\end{array}$ & $\begin{array}{c}\text { Pupation } \\
\text { in } \%\end{array}$ & $\begin{array}{c}\text { Pupal } \\
\text { Mortality } \\
\text { in } \%\end{array}$ & $\begin{array}{c}\text { Deformed } \\
\text { Pupae } \\
\text { in } \%\end{array}$ & $\begin{array}{c}\text { Emerged } \\
\text { Moths } \\
\text { in } \%\end{array}$ & $\begin{array}{c}\text { Deformed } \\
\text { Moths } \\
\text { in } \%\end{array}$ \\
\hline $\mathbf{A}+\mathrm{B} 100 \%$ & $56 \%$ & $2 \%$ & $42 \%$ & $8 \%$ & $0 \%$ & $27 \%$ & $7 \%$ \\
\hline $\mathrm{A}+\mathrm{B} 75 \%$ & $44 \%$ & $0 \%$ & $56 \%$ & $7 \%$ & $6 \%$ & $39 \%$ & $4 \%$ \\
\hline $\mathrm{A}+\mathrm{B} 50 \%$ & $38 \%$ & $0 \%$ & $62 \%$ & $6 \%$ & $0 \%$ & $53 \%$ & $3 \%$ \\
\hline $\mathrm{A}+\mathrm{B} 25 \%$ & $33 \%$ & $2 \%$ & $65 \%$ & $4 \%$ & $0 \%$ & $58 \%$ & $3 \%$ \\
\hline $\mathrm{A}+\mathrm{B} 12.5 \%$ & $19 \%$ & $0 \%$ & $81 \%$ & $2 \%$ & $6 \%$ & $73 \%$ & $0 \%$ \\
\hline Untreated & $0 \%$ & $0 \%$ & $100 \%$ & $0 \%$ & $0 \%$ & $100 \%$ & $0 \%$ \\
\hline
\end{tabular}


Abed - El Wahab, I. S.

( B )

\begin{tabular}{|c|c|c|c|c|c|c|}
\hline \multirow[t]{2}{*}{ Concent. } & \multirow{2}{*}{$\begin{array}{c}\text { Larval } \\
\text { Duration } \\
\text { in(days) } \\
\text { Mean } \pm \text { S.E. }\end{array}$} & \multirow{2}{*}{$\begin{array}{c}\text { Pupal } \\
\text { Duration } \\
\text { in(days) } \\
\text { mean } \pm \text { S.E. }\end{array}$} & \multirow{2}{*}{$\begin{array}{c}\text { Fecundity } \\
\text { no. of egg } \\
\text { /female } \\
\text { Mean } \pm \text { S.E. }\end{array}$} & \multirow{2}{*}{$\begin{array}{c}\text { Hatch. } \\
\text { in } \%\end{array}$} & \multicolumn{2}{|c|}{$\begin{array}{c}\text { Moth } \\
\text { Longevity } \\
\text { in(days) }\end{array}$} \\
\hline & & & & & 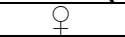 & $0^{\pi}$ \\
\hline $\begin{array}{l}A+B \\
100 \%\end{array}$ & $\begin{array}{c}7.8 \\
( \pm 0.86) \\
\end{array}$ & $\begin{array}{c}8 \\
( \pm 0.44) \\
\end{array}$ & $\begin{array}{c}480 \\
( \pm 59.45)\end{array}$ & $29.3 \%$ & $\begin{array}{c}7.12 \\
( \pm 0.34) \\
\end{array}$ & $\begin{array}{c}6 \\
( \pm 23) \\
\end{array}$ \\
\hline $\begin{array}{l}A+B \\
75 \%\end{array}$ & $\begin{array}{c}7.8 \\
( \pm 0.66)\end{array}$ & $\begin{array}{c}8 \\
( \pm 0.70) \\
\end{array}$ & $\begin{array}{c}540 \\
( \pm 89.77)\end{array}$ & $38.1 \%$ & $\begin{array}{c}7.13 \\
( \pm 0.34) \\
\end{array}$ & $\begin{array}{c}6.21 \\
( \pm 0.31) \\
( \pm 0.3\end{array}$ \\
\hline $\begin{array}{l}A+B \\
50 \%\end{array}$ & $\begin{array}{c}8.6 \\
( \pm 0.74) \\
\end{array}$ & $\begin{array}{c}8.4 \\
( \pm 0.81) \\
\end{array}$ & $\begin{array}{c}660 \\
( \pm 182.29) \\
\end{array}$ & $51.13 \%$ & $\begin{array}{c}7.53 \\
( \pm 0.1) \\
\end{array}$ & $\begin{array}{r}6.62 \\
( \pm 0.72) \\
\end{array}$ \\
\hline $\begin{array}{l}A+B \\
25 \%\end{array}$ & $\begin{array}{c}8.8 \\
( \pm 0.67) \\
\end{array}$ & $\begin{array}{c}8.8 \\
( \pm 0.74) \\
\end{array}$ & $\begin{array}{c}720 \\
( \pm 154.73) \\
\end{array}$ & $57.2 \%$ & $\begin{array}{c}7.9 \\
( \pm 0.33) \\
\end{array}$ & $\begin{array}{r}6.68 \\
( \pm 0.98) \\
\end{array}$ \\
\hline $\begin{array}{l}A+B \\
12.5 \%\end{array}$ & $\begin{array}{c}9.2 \\
( \pm 0.6)\end{array}$ & $\begin{array}{c}8.8 \\
( \pm 0.93)\end{array}$ & $\begin{array}{c}840 \\
( \pm 223.75)\end{array}$ & $64.5 \%$ & $\begin{array}{c}7 \\
( \pm 0.54)\end{array}$ & $\begin{array}{c}6.99 \\
( \pm 0.23)\end{array}$ \\
\hline Untreated & 9 & 8.9 & 2260 & $99.24 \%$ & 8.6 & 8.4 \\
\hline $\begin{array}{l}A=(N P V) \\
F\{5 \%)=5.2\end{array}$ & R12 010 & & $\begin{array}{l}\text { B = B.thu } \\
\text { LSD }=\end{array}$ & $\begin{array}{l}\text { giensis IL } \\
335\end{array}$ & & \\
\hline
\end{tabular}

Table (6) The general means of certain biological aspects of $4^{\text {th }}$ larval instar of Spodoptera littoralis affected by the mixture B.thuringiensis (Diple 2X) and Nuclear polyhedrosis virus (SNPV) throughout the two tested years $(2004 \& 2005)$ at different concentration.

\begin{tabular}{|c|c|c|c|c|c|c|c|}
\hline \multicolumn{8}{|l|}{ (A) } \\
\hline Concent. & $\begin{array}{c}\text { Larval } \\
\text { Mortality } \\
\text { in } \%\end{array}$ & $\begin{array}{c}\text { Deformed } \\
\text { Larvae } \\
\text { in } \%\end{array}$ & $\begin{array}{l}\text { Pupation } \\
\text { in } \%\end{array}$ & $\begin{array}{l}\text { Pupal } \\
\text { Mortality } \\
\text { in } \%\end{array}$ & $\begin{array}{c}\text { Deformed } \\
\text { Pupae } \\
\text { in } \%\end{array}$ & $\begin{array}{c}\text { Emerged } \\
\text { Moths } \\
\text { in } \%\end{array}$ & $\begin{array}{c}\text { Deformed } \\
\text { Moths } \\
\text { in } \%\end{array}$ \\
\hline$A+B \quad 100 \%$ & $55 \%$ & $2.5 \%$ & $42.5 \%$ & $7.5 \%$ & $0 \%$ & $29 \%$ & $6.5 \%$ \\
\hline$A+B \quad 75 \%$ & $42 \%$ & $0.5 \%$ & $57.5 \%$ & $6.5 \%$ & $5 \%$ & $42 \%$ & $4 \%$ \\
\hline$A+B \quad 50 \%$ & $35 \%$ & $0 \%$ & $65 \%$ & $7 \%$ & $0 \%$ & $53.5 \%$ & $4.5 \%$ \\
\hline$A+B \quad 25 \%$ & $28 \%$ & $1.5 \%$ & $70.5 \%$ & $5.5 \%$ & $2 \%$ & $60 \%$ & $3 \%$ \\
\hline$A+B$ 12.5\% & $13.5 \%$ & $0 \%$ & $86.5 \%$ & $5 \%$ & $4.5 \%$ & $74.5 \%$ & $2.5 \%$ \\
\hline Untreated & $0 \%$ & $0 \%$ & $100 \%$ & $2.5 \%$ & $0 \%$ & $97.5 \%$ & $0 \%$ \\
\hline
\end{tabular}

\begin{tabular}{|c|c|c|c|c|c|c|}
\hline \multicolumn{7}{|l|}{ (B) } \\
\hline \multirow[t]{2}{*}{ Concent. } & \multirow{2}{*}{$\begin{array}{c}\text { Larval } \\
\text { Duration } \\
\text { in(days) } \\
\text { mean } \pm \text { S.E. }\end{array}$} & \multirow{2}{*}{$\begin{array}{c}\text { Pupal } \\
\text { Duration } \\
\text { in(days) } \\
\text { mean } \pm S . E .\end{array}$} & \multirow{2}{*}{$\begin{array}{c}\text { Fecundity } \\
\text { no. of egg } \\
\text { /female } \\
\text { Mean } \pm S . E .\end{array}$} & \multirow[t]{2}{*}{$\begin{array}{c}\text { Hatch. } \\
\text { in\% }\end{array}$} & \multicolumn{2}{|c|}{$\begin{array}{c}\text { Moth } \\
\text { Longevity } \\
\text { in(days) }\end{array}$} \\
\hline & & & & & 8 & \\
\hline $\begin{array}{l}A+B \\
100 \%\end{array}$ & $\begin{array}{c}6.8 \\
( \pm 0.61)\end{array}$ & $\begin{array}{c}7 \\
( \pm 0.70)\end{array}$ & $\begin{array}{c}497 \\
( \pm 58.95)\end{array}$ & $43.3 \%$ & $\begin{array}{c}6.71 \\
( \pm 0.23)\end{array}$ & $\begin{array}{c}5.04 \\
( \pm 0.27)\end{array}$ \\
\hline $\begin{array}{l}A+B \\
75 \%\end{array}$ & $\begin{array}{c}6.8 \\
( \pm 0.51)\end{array}$ & $\begin{array}{c}7 \\
( \pm 0.62) \\
\end{array}$ & $\begin{array}{c}583 \\
( \pm 72.21)\end{array}$ & $52.59 \%$ & $\begin{array}{c}6.86 \\
( \pm 0.33)\end{array}$ & $\begin{array}{c}5.71 \\
( \pm 0.44)\end{array}$ \\
\hline $\begin{array}{l}A+B \\
50 \%\end{array}$ & $\begin{array}{c}7.4 \\
\pm 0.52)\end{array}$ & $\begin{array}{c}7.3 \\
( \pm 0.72)\end{array}$ & $\begin{array}{c}698.5 \\
( \pm 167.64)\end{array}$ & $60.51 \%$ & $\begin{array}{c}7.06 \\
( \pm 0.40)\end{array}$ & $\begin{array}{c}6.12 \\
( \pm 0.53)\end{array}$ \\
\hline $\begin{array}{l}A+B \\
25 \% \\
\end{array}$ & $\begin{array}{c}7.6 \\
( \pm 0.67) \\
\end{array}$ & $\begin{array}{c}7.6 \\
( \pm 0.62) \\
\end{array}$ & $\begin{array}{c}796.5 \\
( \pm 175.64) \\
\end{array}$ & $67.14 \%$ & $\begin{array}{c}7.21 \\
( \pm 0.57) \\
\end{array}$ & $\begin{array}{c}6.54 \\
( \pm 0.54) \\
\end{array}$ \\
\hline \begin{tabular}{|l|}
$A+B$ \\
$12.5 \%$ \\
\end{tabular} & $\begin{array}{c}8.4 \\
( \pm 0.64) \\
\end{array}$ & $\begin{array}{c}7.8 \\
( \pm 0.75) \\
\end{array}$ & $\begin{array}{c}902.5 \\
( \pm 239.15) \\
\end{array}$ & $71.78 \%$ & $\begin{array}{c}6.84 \\
( \pm 0.48)\end{array}$ & $\begin{array}{c}6.90 \\
( \pm 0.23) \\
\end{array}$ \\
\hline Untreated & 9 & 8.4 & 2250 & $98.66 \%$ & 9.1 & 8.8 \\
\hline
\end{tabular}

$\mathrm{A}=(\mathrm{NPV}) 5 \times 10^{12} \mathrm{PIB} /$ larvae $\mathrm{B}=$ B.thuringiensis (Diple 2X) IU $F(5 \%)=9.777$

LSD $=1.373$ 


\section{REFERENCES}

Abbott, W. S. (1925): A method for computing the effectiveness of an insecticide. J . Econ . Entomol ., 18:265-267.

Abdel-Aziz, S. Hanan (2000): Physiopathological studies on bacterial infection of cotton leaf worm, Spodoptera littoralis. M. Sc. Thesis, Fac. Sci., Ain Shams Univ. Egypt.

Abdel-Halim (1993). Bioactivity of four commercial Bacillus thuringiensis formulations on some phytophagous lepidopterous insect pests of vegetables. Annals Agric. Sci., Special issue, Egypt.545-553, 1990.

Abdel-Haleem, M. Sawsan (1997): Efficacy and residual effect of some microbial and chemical insecticides against larvae of the cotton leafworm, Spodoptera littoralis (Boisd.). Egypt. J. Biol. Pest Control, 7 (2): 73-78.

Abou-Bakr, H. (1997): Efficacy of different Bacillus thuringiensis formulations against the cotton leafworm, Spodoptera littoralis (Boisduval). Egypt. J. Biolog. Pest Control 7 (1): 7-11.

Aly, A. E.; Esmat, A. K.; Nawal, Z.; Amina, M. A. and Mona, B. R. E. (2000): Effect of Bacillus thuringiensis, a chemical insecticide and its mixtures against the unparasitized and parasitized Spodoptera littoralis (Boisd.) larvae. Egypt. J. Agric. Res., 78 (4): 1587-1600.

Belisle, B.W.;M. Shapiro;E.M. Dougherty; H.A.Rathburn; G.B. Godwin; K.M. Jeong; R.H.Chiarella and D.E.Lynn (1990) Gypsy moth nuclear polyhedrosis virus in cell culture a likely commercial system for viral pesticide production. Invertebrate Pathology and Microbial Control, Adelaide, Australia, 20-24 August 1990. 1990, 12.

Bernhard, K.; Jarrett, P.; Meadows, M.; Butt, J.; Ellis, D.J.; Roberts, G.M.; Pauli, S.; Rodgers, P. and Burges, H.D. (1997). Natural isolates of Bacillus thuringiensis : worldwide distribution, characterization, and activity against insect pests. J. Invertebr. Pathol., 70 (1): 59-68.

Broza, M. and Sneh, B. (1994): B. thuringiensis spp. Kurstaki as an effective control agent of lepidopteran pests in tomato fields in Israel. J. Econ. Entomol., 87(4): 923-928.

Butani, P.G. ; M.N. Kapadia and G.J. Parsana (1997). Comparative efficacy and economics of nuclear polyhedrosis virus (NPV) for the control of Helicoverpa armigera (Hubner) on groundnut. Journal of Oilseeds Research. 14: 1, 85-87.

Chaufaux, J.; Muller-Cohn, J.; Buisson, C.; Sanchis, V.; Lereclus, D. and Pasteur, N. (1997). Inheritance of resistance to the Bacillus thuringiensis CrylC toxin in Spodoptera littoralis (Lepidoptera : Noctuidae). J. Econ. Entomol., 90 (4) : 873-878.

Dabi, R. K.; Puri, M. K.; Gupta, H. C. and Sharma, S. K. (1988): Synergistic response of low rate of $B$. thuringiensis Berliner with sub-lethal dose of insecticides against Heliothis armigera (Hubner). Indian J. Entomol., 50 (1): 28-31.

El-Sayed, A.K. and Lotfy, N. M (1990) Effect of Bacillus sphaericus on Culiseta longiareolate (Macquart). Proc. Int. Conf. St., Comp. SC., Soc. Res. and Dem. 125-137.

Gadallah, A.I.; Emara, S.A.; Nagwa M. Hosein; El-Kordy, M.W. and Sawsan A. Abdel-Halim (1990). Bioactivity of four commercial Bacillus thuringiensis formulations on some phytophagous lepidopterous insect pests of vegetables. Annals Agric. Sci., Special issue, 545-553, 1990. 
Abed - El Wahab, I. S.

Mckinely. D.J. (1985): Nuclear polyhedrosis virus of Spodoprera littoralis boisd (Lepidoptera, Noctuidea) as an infective agent in its host and related indects. Ph. D. Thesis. University of London.

Morris, O. N.; Trottier, M.; Converse, V. and Kanagaratnam, P. (1996): Toxicity of Bacillus thuringiensis subsp. aizawai for Mamestra configurata (Lepidoptera: Noctuidae)J.Econ. Entomol., 89 (2): 359-365.

Snedecor, G.W. (1971) . Methods of Statistical Analysis. Iowa State Univ. Press, Ames, lowa, USA.

Peng, H.Y.; T.N. Xie; F. Jing; Y.L. Zhang and Y. Liu (1992) Study on new viral pesticide with high effect and without environmental pollution in China Biochemical-and-Biohysical-Research- Communications. 189:1, $680-683$

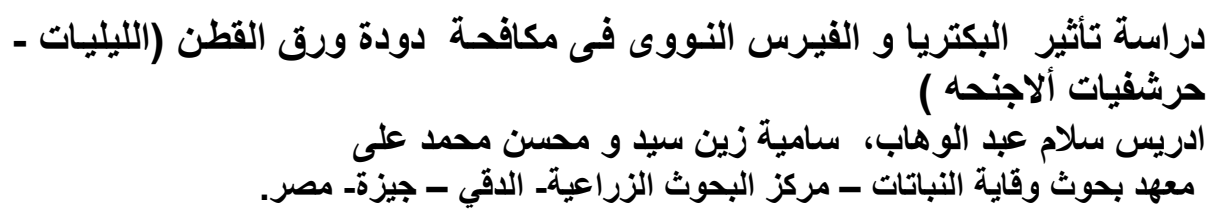

أجريت هذه الدراسـة لدراسة تأثثر مخلوطُ مـع المركب الحيوي (فيرس البولي هيدروذس فيرس) وبكتريـا

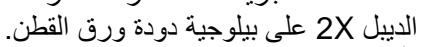

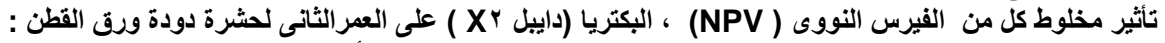

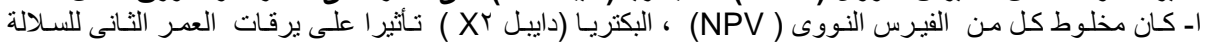

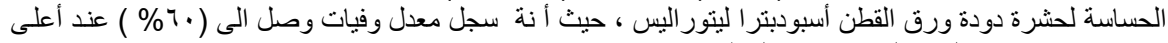

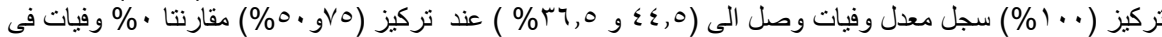
اليرقات الغير المعاملة.

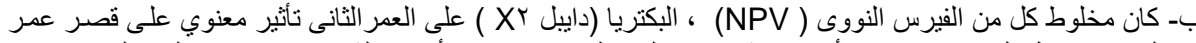

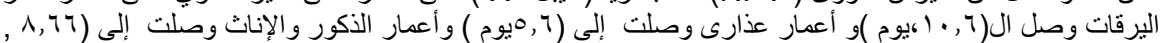

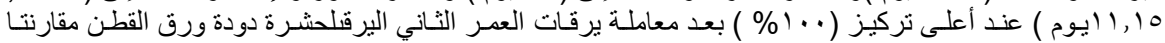

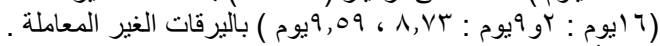

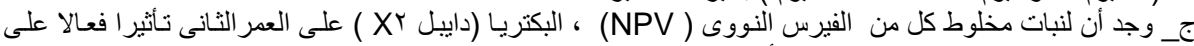

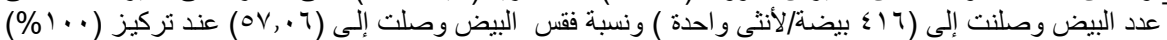

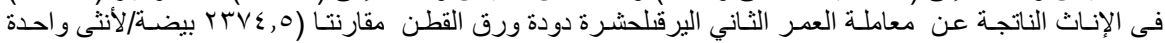

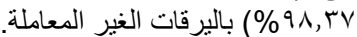

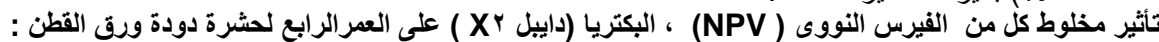

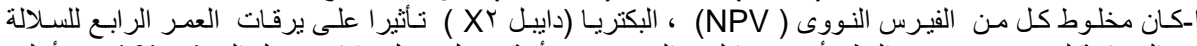

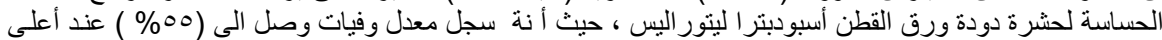

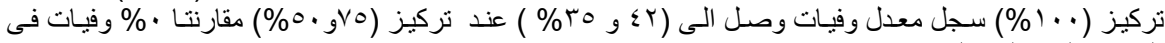

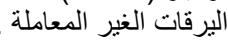

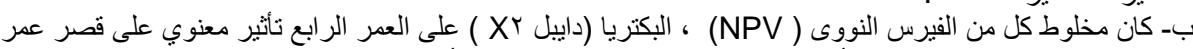

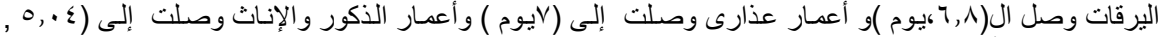

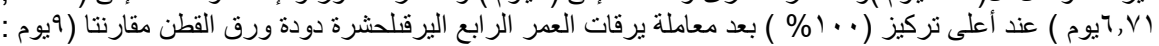

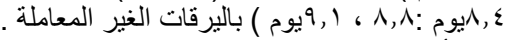

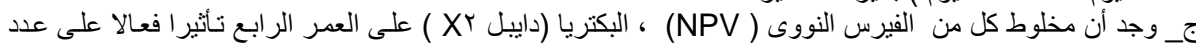

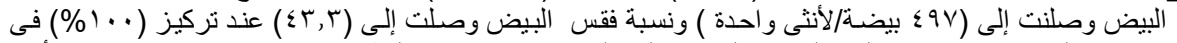

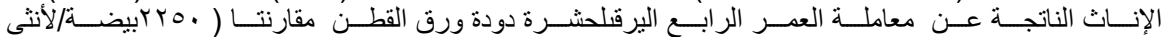

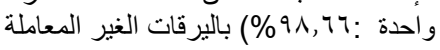

